I have to repeat again, and apologize for, my inability to give much indication of the effect of ageing on total daily energy expenditure. We have, however, seldom found much obvious difference between the mean values for comparable populations; the mean energy output of sedentary men aged about 60 we have measured as about $2600 \mathrm{kcal} /$ day, which is similar to values found for young men. Our elderly forestry workers expended over $3500 \mathrm{kcal} / \mathrm{day}$, and the farmers over $3500 \mathrm{kcal} /$ day. Several individuals reached levels of up to $4500 \mathrm{kcal} /$ day although none of our Scottish subjects approached the $5000 \mathrm{kcal} /$ day of one of the elderly Swiss peasants we studied.

From our measurements on women, a small effect of age on energy output seems obvious. The mean values are usually low for all age groupings, means of 2200 $\mathrm{kcal} /$ day for young women comparing with $2100 \mathrm{kcal} /$ day in middle-aged women and about $2000 \mathrm{kcal} /$ day in the elderly. The upper limit of the range is very much lower for elderly women than for men, $3000 \mathrm{kcal} /$ day being the maximum we have seen in Scotland; I hesitate to say that we obtained a value of $3900 \mathrm{kcal} /$ day for a Swiss peasant woman.

I have only scratched the surface of this problem of age and physical activity. It is an interesting problem and likely to have much medical and sociological significance. It would be pleasant to think that the accumulation of new experimental information might induce the Society to repeat this Symposium in a few years time.

Some of the earlier studies reported in this paper were supported by a grant from the Medical Research Council. Most of the work, however, was supported by US Public Health Service Grant AM 05 104-05.

\title{
Food intakes and weight changes in climatic extremes
}

By O. G. Enholm and R. Goldsmith, Division of Human Physiology, National Institute for Medical Research, London, $\mathrm{NW}_{3}$

For a number of years field studies of food intake, weight changes and energy expenditure have been made by members of the Division of Human Physiology in regions of climatic extremes. Long-term studies have been made in Antarctica on members of the British Antarctic Survey (BAS) while shorter-term studies have been made on soldiers in the hot, humid climate of Aden.

\section{Cold-climate studies}

Climate, exposure and activity. The climates of the stations of the BAS where observations have been made are very severe: yearly mean temperatures range from $-20^{\circ}$ at Halley Bay $\left(75^{\circ} 26^{\prime} \mathrm{S}\right)$ to $-4^{\circ} 6^{\circ}$ at the Argentine Islands $\left(65^{\circ} \mathrm{r} 3^{\prime} \mathrm{S}\right)$. The cooling effects of the low temperatures are multiplied by the fairly constant wind. On the other hand, the climatic stress is mitigated by the high thermal radiation from the sun, both direct and reflected (Chrenko \& Pugh, 196r-2). Furthermore, it has been shown (Norman, 1965) that much of the time is spent in the shelter of the hut 25 (2) 3 
or tent where more temperate conditions prevail. In addition, when outdoors, men are usually working fairly hard and they wear adequate clothing for comfort (Goldsmith, I960); it is only the extremities, hands, feet and face, that are subjected to severe cooling.

The climate and the way of life, however, impose conditions which make considerable demands on energy expenditure. Stores have to be dug out of the snow, which often has the consistency of concrete, snow must be collected for water supplies, and heavy loads must be carried (Goldsmith, I959). The chores of housekeeping are made more difficult by the relatively primitive design of dwellings and the overriding necessity to keep them heated.

Much of the scientific work necessitates travelling long distances from the station, mainly with dog sledges. During sledging the energy expenditure is particularly high; the dog driver not only has to ski beside his sledge continuously for 8-io h a day, but also, over rough ground, the sledge has to be man-handled, and sometimes loads may be relayed up steep slopes. Rations are nearly always strictly limited in order to save weight and bulk.

Energy balance. Food intake and weight changes have been studied during sledging journeys and at the stations. J. M. Adam (personal communication), using the integrated motor pneumotachograph (IMP), measured an expenditure of $500 \mathrm{kcal} / \mathrm{h}$ for $8 \mathrm{~h}$ during sledging. The energy expenditure varies considerably during a journey, as weather can prevent travel and the sledgers may have to spend the day lying up in tents. The terrain is also very variable, and distances covered do not necessarily relate to the physical work involved. Table $\mathrm{I}$ summarizes the results of observations,

Table I. Body-weight and energy intake of men during sledging

\begin{tabular}{|c|c|c|c|c|c|c|}
\hline Reference & $\begin{array}{c}\text { Body-wt } \\
(\mathrm{kg})\end{array}$ & $\begin{array}{l}\text { Period } \\
\text { (days) }\end{array}$ & $\begin{array}{l}\text { Intake } \\
\text { (kcal) }\end{array}$ & $\begin{array}{l}\text { Expenditure } \\
\text { (kcal) }\end{array}$ & $\begin{array}{l}\text { Wt change } \\
(\mathrm{kg})\end{array}$ & Location \\
\hline $\begin{array}{l}\text { Masterton, Lewis \& } \\
\text { Widdowson (1957) }\end{array}$ & $\begin{array}{l}70.00 \\
77.00 \\
83.00 \\
87.00\end{array}$ & $\begin{array}{l}19 \\
19 \\
10 \\
10\end{array}$ & $\begin{array}{l}4520 \\
4850 \\
4870 \\
4840\end{array}$ & $\begin{array}{l}5010 \\
5120 \\
5310 \\
5350\end{array}$ & - & Greenland \\
\hline Norman (1960) & $\begin{array}{l}85.00 \\
88.00 \\
83.00 \\
67.00\end{array}$ & $\begin{array}{l}4 \\
4 \\
4 \\
4\end{array}$ & $\left.\begin{array}{l}4260 \\
4400 \\
4700 \\
4350\end{array}\right\}$ & Mean, 5050 & $\begin{array}{l}-2.1 \\
-0.3 \\
-2.4 \\
-I .3\end{array}$ & Halley Bay \\
\hline Orr $(1962,1965)(a)$ & $\begin{array}{l}58 \cdot 00 \\
81 \cdot 75 \\
89 \cdot 50\end{array}$ & $\begin{array}{l}33 \\
33 \\
33\end{array}$ & $\begin{array}{l}4500 \\
4500 \\
4500\end{array}$ & $\begin{array}{l}(4900) \\
(4950) \\
(5130)\end{array}$ & $\begin{array}{l}-2.0 \\
-2.25 \\
-3.25\end{array}$ & $\begin{array}{l}\text { Hope Bay, } \\
\text { Grahamland }\end{array}$ \\
\hline (b) & $\begin{array}{l}81.00 \\
69 \cdot 00 \\
63.00\end{array}$ & $\begin{array}{l}70 \\
70 \\
70\end{array}$ & $\begin{array}{l}5000 \\
5000 \\
5000\end{array}$ & $\begin{array}{l}(5000) \\
(5000) \\
(4890)\end{array}$ & $\begin{array}{l} \pm 0 \\
\pm 0 \\
+1 \cdot 25\end{array}$ & \\
\hline (c) & $\begin{array}{l}83.00 \\
69.00\end{array}$ & $\begin{array}{l}16 \\
16\end{array}$ & $\begin{array}{l}3900 \\
3900\end{array}$ & $\begin{array}{l}(6000) \\
(4410)\end{array}$ & $\begin{array}{l}-5 \cdot 0 \\
-I \cdot 25\end{array}$ & \\
\hline $\begin{array}{l}(d) \\
(e)\end{array}$ & $\begin{array}{l}79 \cdot 25 \\
79 \cdot 75 \\
81 \cdot 50 \\
81 \cdot 50 \\
93 \cdot 00\end{array}$ & $\begin{array}{l}13 \\
13 \\
18 \\
18 \\
18\end{array}$ & $\begin{array}{l}4100 \\
4100 \\
5600 \\
5600 \\
5600\end{array}$ & $\begin{array}{l}(4725) \\
(5250) \\
(5500) \\
(6300) \\
(6500)\end{array}$ & $\begin{array}{l}-1.25 \\
-2.25 \\
+0.25 \\
-2.0 \\
-2.5\end{array}$ & \\
\hline
\end{tabular}

Mean 'expenditure': $5260 \mathrm{kcal} /$ day. Expenditure figures in parentheses calculated from food intake and weight change, assuming $\mathrm{I} \mathrm{kg}$ wt change $=6500 \mathrm{kcal}$. 
including direct estimates of energy expenditure from time and motion study as well as estimates from weight changes. The daily energy expenditure on journeys of 4-70 days averages $5250 \mathrm{kcal}$, ranging from 4410 to 6900 . Orr ( 1965$)$ reported that three men on one journey of 70 days, described as not arduous and with frequent halts, given a free choice of ration had a daily intake of $5000 \mathrm{kcal}$ and there was virtually no weight lost. They travelled on average only $3.5 \mathrm{miles} / \mathrm{day}$. On another journey of 19 days at the average rate of $2 \mathrm{I}$ miles/day, the men consumed $5600 \mathrm{kcal}$ daily (rations again unrestricted) but two of the three men lost weight.

At base camp, work also tends to be relatively heavy, but food is freely available and there is considerable choice. Over the period of a year there is usually a slight weight gain. Out of sixty subjects for whom there are weight records throughout the year, only ten lost weight, four showed no change and forty-six gained weight. The overall change was a weight gain of approximately $2 \mathrm{~kg}$.

Table 2. Body-weight and energy intake of men at Polar bases

\begin{tabular}{|c|c|c|c|c|c|c|}
\hline \multirow{2}{*}{ Reference } & \multirow{2}{*}{$\begin{array}{l}\text { Body-wt } \\
\quad(\mathrm{kg})\end{array}$} & \multirow{2}{*}{$\begin{array}{l}\text { Period } \\
\text { (days) }\end{array}$} & \multicolumn{2}{|c|}{ Intake (kcal) } & \multirow{2}{*}{$\begin{array}{l}\text { Expenditure } \\
\text { (kcal) }\end{array}$} & \multirow[b]{2}{*}{ Location } \\
\hline & & & Mean value & Range & & \\
\hline \multirow{8}{*}{$\begin{array}{l}\text { Masterton, Lewis \& } \\
\text { Widdowson (1957) (a) }\end{array}$} & $77 \cdot 00$ & 7 & 3300 & & 3170 & Greenland \\
\hline & $70 \cdot 00$ & 7 & 3600 & & 3400 & \\
\hline & 83.00 & 7 & 3600 & & 3780 & \\
\hline & 87.00 & 7 & 5090 & & 3620 & \\
\hline & 77.00 & 7 & 3780 & & 3310 & \\
\hline & 70.00 & 7 & 3570 & & 3660 & \\
\hline & 83.00 & 4 & 39 I0 & & 3560 & \\
\hline & 87.00 & 4 & $444^{\circ}$ & & 3570 & \\
\hline $\begin{array}{l}\text { A. F. Rogers } \\
\text { (personal communication) }\end{array}$ & 84.00 & 7 & 4100 & $3400-5310$ & $4 r 00$ & $\begin{array}{l}\text { Shackleton, } \\
\text { Antarctic }\end{array}$ \\
\hline Davies (1962) & $76 \cdot 00$ & 12 & 3300 & $2850-394^{\circ}$ & & Stonnington \\
\hline \multirow[t]{25}{*}{ Easty (1966) } & 83.00 & 8 & 3990 & $3180-4770$ & & Halley Bay \\
\hline & 72.00 & 8 & 3110 & $2630-3370$ & & \\
\hline & 102.00 & 8 & 4180 & $3150-5910$ & & \\
\hline & 74.00 & 8 & 3000 & $2130-3850$ & & \\
\hline & $90 \cdot 00$ & 8 & $335^{\circ}$ & $2690-4230$ & & \\
\hline & 80.50 & 8 & 3630 & $2690-5000$ & & \\
\hline & 75.00 & 8 & 3590 & $2790-45^{80}$ & & \\
\hline & $96 \cdot 50$ & 8 & 5260 & $4200-5730$ & & \\
\hline & $71 \cdot 50$ & 8 & 3630 & $2850-4290$ & & \\
\hline & 66.50 & 8 & 3230 & $2780-3770$ & & \\
\hline & $74 \cdot 50$ & 8 & 3920 & $2970-6420$ & & \\
\hline & 80.00 & 8 & 2750 & $1850-3380$ & & \\
\hline & $98 \cdot 40$ & 8 & 5120 & $4030-6620$ & & \\
\hline & $63 \cdot 30$ & 8 & 3590 & $2500-4500$ & & \\
\hline & 67.80 & 8 & 3790 & $2750-4860$ & & \\
\hline & $73 \cdot 80$ & 8 & 2670 & $2140-3590$ & & \\
\hline & $75 \cdot 50$ & 8 & 3610 & $3130-4420$ & & \\
\hline & $69 \cdot 40$ & 8 & 3500 & $2620-4770$ & & \\
\hline & $70 \cdot 80$ & 8 & 3560 & $2730-4620$ & & \\
\hline & 68.40 & 8 & 3400 & $2340-4130$ & & \\
\hline & 63.00 & 8 & 3310 & $2720-4140$ & & \\
\hline & $6 I \cdot 50$ & 8 & 3360 & $2920-4090$ & & \\
\hline & $80 \cdot 20$ & 8 & 2910 & $2050-3860$ & & \\
\hline & $68 \cdot 30$ & 8 & $285^{\circ}$ & $1630-3820$ & & \\
\hline & 87.00 & 8 & 4630 & $2450-6860$ & & \\
\hline
\end{tabular}


Energy expenditure has been estimated, using time and motion methods, and A. F. Rogers (personal communication) has made measurements of oxygen consumption with the IMP. He studied one subject at Shackleton Base $\left(78^{\circ} \mathrm{S}\right)$ for $\mathrm{I}$ week, measuring food intake as well. The subject was in calorie balance at a daily expenditure of 4100 kcal. The various studies made are summarized in Table 2. At British bases in the Antarctic the intake averaged $3610 \mathrm{kcal} / \mathrm{day}$, with a wide range of from $2 \mathrm{I} 80$ to 5720 . Masterton et al. (1957) measured an average daily intake of $3900 \mathrm{kcal}$ in Greenland, but they showed that their subjects were in positive balance as they estimated daily energy expenditure at $3600 \mathrm{kcal}$.

There has been one detailed dietary study in an American polar base (Milan \& Rodahl, 196I), where conditions of life are different in many respects from those in the British stations. There a larger food intake was observed but the men also had a considerable weight gain. The average daily energy expenditure was estimated to be $3740 \mathrm{kcal}$ and the daily food intake $4250 \mathrm{kcal}$; there was a weight gain which averaged about $4 \cdot 5 \mathrm{~kg}$.

Although the composition of the diet at the British base camp is not constant, the proportion of calories derived from fat averaged approximately $38 \%$, ranging from $32.5 \%$ to $45 \%$ in the different surveys. The sledging rations contain a much higher proportion of fat, $57 \%$. This is not necessarily a matter of choice but is due to the need to conserve weight and reduce bulk.

\section{Hot-climate studies}

The effect of hot climates has been studied by comparison of the food intakes of men doing similar tasks in the UK and in Aden (Edholm, Fox, Goldsmith, Hampton, Underwood, Ward, Wolff, Adam \& Allan, I964).

Two groups of men were studied. Both groups were exceptionally fit, and the only important difference was that one group (A) had spent a year in Bahrein before the experiment and the second group (B) had never previously been exposed to heat. Group B was first studied in the UK for 12 days, of which the first 4 days consisted of hard work, the next 4 days were mainly sedentary, and the final days were again occupied with hard work. This part of the study was carried out in cool weather, and then the members of group B were flown to Aden where they were joined by group $A$ and where a programme similar to the Iz-day study in the UK was completed. Both groups then returned to the UK for a repeat of the I2-day study.

Climate, exposure and activity. The climatic conditions of Aden during these studies were hot and fairly humid. The subjects, who lived in tented accommodation and were out of doors all day, bore the full brunt of the heat. The day-time drybulb temperature very rarely fell below $30^{\circ}$, wet-bulb ranged from 24 to $29^{\circ}$ (r.h. 40-90\%), and solar radiation was also high.

Energy expenditures, estimated from detailed time and motion observations, were similar in all three 12 -day periods, although group $A$, who were acclimatized to heat, had a slightly smaller expenditure than group B. The energy expenditure was estimated to be approximately $4000 \mathrm{kcal}$ on the 'hard' days and $2600 \mathrm{kcal}$ during the 'quiet' days. 
Energy balance. Similar food was provided on all three occasions, and within this limitation the men had a free choice. The mean food intake in Aden was approximately $25 \%$ less than the corresponding intake in the UK. However, the balance of the diet remained similar. The proportion of calories coming from fat was $37 \%$ in the UK and $34 \%$ in Aden; the figures for carbohydrates were $52 \%$ and $55 \%$, and protein provided I $\%$ in both UK and Aden.

Water was freely available and the men were encouraged to drink it, particularly in Aden. Average intakes in Aden in the first 4 days were 7.51 . for group A and $8 \cdot 71$. for group $B$.

Both groups lost weight in the $\mathrm{I} 2$ days in Aden-group A lost $2.5 \mathrm{~kg}$ and group B $\mathbf{I} \cdot \mathbf{I} \mathrm{kg}$-whereas in the final UK phase both groups put on weight-O.I kg and $0.6 \mathrm{~kg}$ respectively. It was considered that the weight lost in Aden did not result from dehydration as water was drunk freely and the weight loss was not quickly recovered on return to the $\mathrm{UK}$.

\section{Discussion}

The results of these observations in cold and hot climates indicate a striking difference in energy balance under these two extremes.

The evidence in the cold climate seems to suggest that food intake is not directly influenced by low environmental temperatures, though men in general show a weight gain over a year of approximately $2.0 \mathrm{~kg}$, whereas similar men in the UK gain only $0.25 \mathrm{~kg}$ (Lewis, Masterton \& Rosenbaum, 1960). On sledging expeditions, with high energy expenditures, weight loss is usual but can be avoided if food is freely available.

The situation in the heat seems to be rather different; hard work in a hot humid climate leads to a pronounced fall in weight not due to temporary dehydration. The comparison of energy balance in a temperate and hot climate is equally striking, showing a $25 \%$ decrease in food intake in the heat when the energy output remains similar.

The effect of climatic extremes on food requirements is still a matter of some controversy. The FAO (1957) recommendation is 'that requirements should be increased by $3 \%$ for every $10^{\circ} \mathrm{C}$ of mean annual external temperature below the reference temperature of $10^{\circ} \mathrm{C}$ ', and 'that requirements should be decreased by $5 \%$ for every $10^{\circ} \mathrm{C}$ of mean annual external temperature above the reference temperature.' More recently, in the Recommended Dietary Allowances of the (USA) National Research Council ( 1964 ), it is said that 'there does not appear to be any reason to increase calorie allowances for activity in the cold'; and in the heat 'it would seem desirable under conditions of increased physical activity to increase calorie allowances by at least 0.5 per cent for every degree rise between 30 and $40^{\circ} \mathrm{C}$.'

As far as polar conditions are concerned, the only reason for an increase in energy expenditure for specific tasks would be due to the extra weight and hobbling effect of clothing (Gray, Consolazio \& Kark, I95I). The BMR at polar bases is not elevated (Wilson, 1956; Lewis, Masterton \& Rosenbaum, 196r).

In hot climates, small reductions in the BMR have been reported and denied 
(Malhotra, Ramaswamy \& Ray, r 960). It is well established that the energy expenditure for specific tasks is directly related to body temperature (Christensen, I933; Consolazio, Shapiro, Masterson \& McKinzie, r96r; Durnin \& Haisman, I966), and in very hot climates body temperature is raised (Edholm et al. 1964).

However, hot climates appear to depress appetite and also place a restriction on the level of work output. The depression of food intake during heavy work in the heat was quite clear cut; large amounts of food palatable in a temperate climate were left untouched, leading to a pronounced negative energy balance. This depression of food intake may be attributed to raised body temperature, though work in temperate climates will also raise body temperature to high levels (Nielsen, 1938). Hamilton ( 1962 ) has suggested that conductivity may be the primary influence in appetite control. In cold climates, with a low skin temperature there is low conductivity leading to appetite stimulation; in the heat, the opposite effect may lead to depression.

It is clearly necessary to distinguish between the effects of environment on food requirements, on appetite and on the ability to perform hard work. The energy cost of similar tasks may not be very different in very hot or very cold climates, but is probably higher in both than in temperate climates. Appetite is clearly depressed in the heat and may be stimulated in the cold. The ability to perform hard work in the heat is limited by the rise in body temperature; in the cold there is no such limitation, the energy expenditure of sledging would not be tolerated in the heat. Thus, both hard work in the heat and appetite are temperature limited. However, under normal conditions of life in the developing tropical countries it is unlikely that the temperature limitation to work is often relevant, and it thus appears to be illogical to base food requirements on environmental temperatures.

\section{REFERENCES}

Chrenko, F. A. \& Pugh, L. G. C. E. (196I-2). Proc. R. Soc. B I55, 243.

Christensen, E. H. (1933). Arbeitsphysiologie 7, 120.

Consolazio, C. F., Shapiro, R., Masterson, J. E. \& McKinzie, P. S. L. (1961). F. Nutr. 73, 126.

Davies, A. G. (I962). Observations on urine, saliva and sweat of men living in the Antarctic. MD Thesis, University of St Andrews.

Durnin, J. V. G. A. \& Haisman, M. F. (rg66). F. Physiol., Lond. (In the Press.)

Easty, D. L. (1966). Br. F. Nutr. (In the Press.)

Edholm, O. G., Fox, R. H., Goldsmith, R., Hampton, I. F. G., Underwood, C. R., Ward, E. J., Wolff, H. S., Adam, J. M. \& Allan, J. R. (I964). Rep. med. Res. Coun., Lond.: Army Personnel Research Committee no. APRC 64/16.

F.A.O. (1957). F.A.O. nutr. Stud. no I 5 .

Goldsmith, R. (1959). Lancet i, 74I.

Goldsmith, R. (1960). F. appl. Physiol. 15, 776.

Gray, E. L., Consolazio, F. C. \& Kark, R. M. (195I). F. appl. Physiol. 4, 270.

Hamilton, C. L. (1962). Int. physiol. Congr. xxr. Leiden. Vol. I, Part 2, p. 686.

Lewis, H. E., Masterton, J. P. \& Rosenbaum, S. (1960). Clin. Sci. 19, 552.

Lewis, H. E., Masterton, J. P. \& Rosenbaum, S. (196r). . . appl. Physiol. 16, 397.

Malhotra, M. S., Ramaswamy, S. S. \& Ray, S. N. (I g6o). \%. appl. Physiol. r5, 769.

Masterton, J. P., Lewis, H. E. \& Widdowson, E. M. (1957). Br. F. Nutr. II, 346.

Milan, F. A. \& Rodahl, K. (196r). F. Nutr. 75, r 52.

National Research Council. (1964). Publs natn. Res. Coun., Wash. no. I 146.

Nielsen, M. (1938). Skand. Arch. Physiol. 79, 193.

Norman, J. N. (1960), Man in the Antarctic, MD Thesis, University of Glasgow, 
Norman, J. N. (1965). Bull. British Antarctic Survey no. 6, 1.

Orr, N. W. M. (1962). Food requirements on Antarctic expeditions. MD Thesis, University of Cambridge.

Orr, N. W. M. (1965). Br.F. Nutr. 19, 79.

Wilson, O. (1956). Metabolism 5, 543. 